\title{
POTRET LAIN PERJALANAN HUKUM DI KERAJAAN BANJAR
}

\author{
M. Faqih de Ridha*
}

\begin{abstract}
Hukum adalah nilai sekaligus pedoman praktis manusia dan masyarakat dalam mengatur dinamika kebidupan dan interaksi sosial. Walaupun demikian pentingnya arti sebuah bukum di masyarakat, bukan berarti bukum lalu menjadi sesuatu yang berdiri sendiri dalam perkembangannya. Hukum pada dasarnya juga memerlukan perangkat kuat di luar dirinya untuk pelaksanaannya. Artinya, barus ada kekuatan yang mampu mengatur dan menjamin bukum untuk bisa hidup di tengah-tengah masyarakat. Oleh karenanya, bukum menjadi sesuatu yang kental dengan perbenturan tanpa henti dengan kehendak-kehendak zaman dimana bukum tersebut ada. Refleksi seperti inilah yang ingin dibangun oleh penulis artikel ini dalam memotret perjalanan bukum Islam selama masa kerajaan Banjar di era Sultan Tabmidullab (1761-1801) dan Sultan Adam (1825-1857).
\end{abstract}

Kata kunci: undang-undang, kerajaan Banjar, politik, masyarakat.

\section{Pendahuluan}

Hukum adalah nilai sekaligus pedoman praktis manusia dan masyarakat dalam mengatur dinamika kehidupan dan interaksi sosial. Hukum pula yang menjamin bahwa masyarakat diikat oleh aturan main yang harus dihormati dan dijalankan secara sadar atas nama keteraturan dan keseimbangan sosial. Walaupun demikian, hukum memerlukan perangkat kuat agar bisa dilaksanakan. Artinya, harus ada kekuatan yang mampu mengatur dan menjamin hukum bisa hidup di masyarakat. Ini berarti pula bahwa hukum memerlukan kekuasaan yang mengatasi masyarakat. Singkat kata, jalannya

\footnotetext{
* Penulis adalah alumnus fakultas Syari'ah IAIN Sunan Kalijaga Jogjakarta, Sekarang
} berwiraswasta dan menetap di Jogjakarta 
hukum sangat dipengaruhi oleh kekuasaan politik. Karena itu, hukum dan kekuasaan memiliki jalinan yang sangat erat di masyarakat.

Tulisan ini tidak memaparkan semua perjalanan hukum dari awal Kerajaan Banjar berdiri hingga fase keruntuhan. Tetapi hanya mengambil dua periode yang cukup mengemuka dalam sejarah hukum Kerajaan Banjar. Yaitu, era Sultan Tahmidullah (1761 - 1801) dan Sultan Adam (1825 - 1857). Di samping itu, tulisan ini tidak ditujukan untuk menghakimi masa lalu. Bagi penulis, berbicara sejarah bukan bicara benar atau salah. Tetapi bagaimana kita bisa mendudukan masa lalu apa adanya. Apapun yang terjadi, itu menjadi pilihan yang harus diambil oleh pelaku sejarah kala itu.

Berbicara perjalanan hukum di Kerajaan Banjar tidak bisa dilepaskan begitu saja dengan konteks yang berlangsung ketika itu. Sebab, ini terkait dengan peran kelompok elit di masyarakat yang sangat signifikan dan kepentingan jangka panjang penguasa. Namun sayang, berita-berita masa lalu Kerajaan Banjar tidak semuanya terekam dengan baik. Kalaupun ada, catatancatatan tersebut tidak mampu menjelaskan secara utuh fakta yang terjadi. Tetapi, ini tidak begitu menghalangi kita untuk menelusuri sejarah hukum yang kita bicarakan saat ini.

\section{Latar Belakang Sosial Politik}

Masa Sultan Tahmidullah dan Sultan Adam merupakan yang paling populer di antara penguasa-penguasa Kerajaan Banjar yang lainnya. Sepak terjang mereka dalam mengatur pemerintahan serta situasi yang berlangsung ketika itu penuh dengan benturan sehingga dinamika sejarah mereka berdua memiliki tempat tersendiri dalam sejarah Raja-Raja Banjar.

Kita mulai dari Sultan Tahmidullah yang berkuasa dari 1761 - 1801. dia adalah putra Sultan Tamjidullah (1734 - 1759). Dia dikenal dengan nama Pangeran Nata Negara yang masyhur dengan sebutan Susuhunan Nata Alam. Ayahnya adalah penguasa Banjar dimana kekuasaannya direbut oleh keponakannya sendiri, yaitu Pangeran Muhammad atau Ratu Anom yang bergelar Sultan Muhammad Aliuddin Aminullah (1759 - 1761). Perebutan ini terjadi sebab Sultan Tamjidullah bukanlah orang yang berhak atas tahta. Namun, karena saat itu Pangeran Muhammad belum dewasa, kekuasaan dijalankan dan kemudian diambil alih oleh Sultan Tamjidullah.

Hingga tahun 1747 Kerajaan Banjar sebenarnya masih kuat baik kedalam ataupun keluar. Tidak ada intervensi atas Kerajaan Banjar dalam mengatur 
wilayah kekuasaannya. Secara tidak langung, ini memperlihatkan bahwa pihak luar tidak mudah untuk menguasai tanah Banjar. Saat itu, pihak barat serta orang-orang Makassar mengincar Banjar. Pada tahun 1747 ini pula Sultan Tamjidullah melakukan kontrak dengan VOC hingga tahun 1787. kontrak ini adalah dasar bagi hubungan politik dan dagang Kerajaan Banjar dengan VOC. Di tahun 1756 kontrak kembali diadakan. Kontrak ini sebenarnya merupakan taktik Tahmidullah untuk memperkuat kekuasaannnya berhadapan dengan pihak lain serta pihak Bugis dan Pangeran Muhammad, namun siasat ini mampu dibaca VOC dan dianggap tidak menguntungkan. Akhirnya ketika Pangeran Muhammad menyerang, Sultan Tamjidullah kalah dan menyerahkan tahta kepada keponakannya itu, namun Pangeran Muhammad tidak lama berkuasa. ${ }^{1}$

Ketika Pangeran Muhammad wafat, sejarah kembali terulang. Anakanaknya yang masih belum dewasa terhalang menjadi penguasa. Padahal, menurut cerita, Ratu Anom menunjuk anaknya Pangeran Abdullah menjadi Raja. Kesempatan ini tidak disia-siakan oleh Nata Alam. Ia pun mengambil alih kekuasaan sembari menyingkirkan putra-putra Pangeran Muhammad. Di antara tiga orang putranya, hanya Pangeran Amir yang berhasil lolos dan kemudian bergabung dengan pihak Bugis di Pagatan (sebagian ada yang mengatakan di Pasir). Sedangkan Pangeran Abdullah dan Pangeran Rahmat ditangkap dan dibunuh. Pangeran Amir yang merasa dirugikan oleh kudeta Nata Alam bermaksud untuk mengambil alih kembali tahta yang pernah menjadi haknya. Namun serangan ini mampu dipatahkan oleh Banjar lewat dukungan Belanda.

Selama berkuasa Sultan Tahmidullah membuat beberapa terobosan. Pertama, menjaga dinasti keturunannya supaya tetap berkuasa dengan cara melakukan pengangkatan anaknya yang baru berumur 6 tahun pada tahun 1767 sebagai Sultan Sulaiman Sa'idullah dan cucunya pada tahun 1782 dengan gelar kehormatan, Sultan Adam. Kedua pewaris tahta ini selanjutnya menjadi penguasa Banjar hingga dihancurkan Belanda. ${ }^{2}$ Kedua, banyak kontrak yang dilakukannya dengan Belanda. Ini merupakan siasat Tahmidullah untuk memperkuat basis pertahanan Kerajaan Banjar terhadap serangan-serang luar terutama dari pasukan Bugis bersama pangeran Amir yang berhasrat mengambil alih kekuasaannya. Tahmidullah sangat sadar dengan kekuatan Banjar yang sangat lemah. Utnuk mengatasinya ia meminta bantuan Belanda.

${ }^{1}$ Muhammad Idward Saleh, Bandjarmasin, Bandung, Balai Pendidikan Guru, 1958, hlm. 94

${ }^{2}$ Muhammad Idward Saleh, Bandjarmasin, hlm. 95 
Kompensasinya adalah penandatanganan kontrak tahun 1787 dimana Belanda dijanjikan mendapatkan wilayah yang sangat luas. Disamping itu, Belanda juga berwenang untuk menentukan siapa yang akan berkuasa di Kerajaan Banjar dan mengakui kekuasaan Tahmidullah beserta keturunannya. ${ }^{3}$ Namun, itu semua hanya sandiwara politik belaka. Sebab, pada kenyataannya Tahmidullah tidak pernah menjalankan kontrak tersebut. Malah sebaliknya, ia mengirim utusan kepada pasukan inggris untuk menentang Belanda supaya angkat kaki dari basis kekuasannya di Batavia. ${ }^{4}$

Politik yang dijalankan oleh Tahmidullah memang licin bahkan tampak licik. Namun, di luar itu semua, ada kemungkinan bahwa apa yang dilakukan Tahmidullah adalah untuk menjaga keutuhan Kerajaan Banjar dan yang paling penting adalah menjaga keutuhan keturunannya sebagai dinasti penguasa Kerajaan Banjar. Namun demikian, satu catatan politik Tahmidullah adalah kekuasaanya didapat melalui kudeta yang tidak lazim. Sebab, ia bukan orang yang berhak atas tahta Kerajaan Banjar.

Catatan-catatan politik tadi agak kontras dengan catatan-catatan sosial masyarakat Kerajaan Banjar. Kita hampir kesulitan menemukan catatancatatannya kecuali apa yang tersirat dari perjalanan politik Kerajaan Banjar. Pergolakan politik di tingkat elit sedikit banyak berpengaruh terhadap masyarakat. Setidaknya ada perbedaan arah dukungan antara masyarakat umum dengan elit Kerajaan terhadap siapa yang berkuasa. Misalnya, ketika Tahmidullah berkuasa, ia didukung oleh pihak bangsawan yang tergabung dalam dewan mahkota sedangkan masyarakat bersimpati kepada Pangeran Amir.

Konflik Kerajaan lewat perang dengan musuh-musuhnya juga sangat merugikan masyarakat. Infra-struktur sosial banyak yang hancur. Pembakaran ibu kota, pembunuhan serta intimidasi terhadapa rakyat tak bersalah, penghancuran lahan pertanian adalah sebagian besar akibat yang ditimbulkan oleh perang. Bagaimana sebenarnya keberadaan masyarakat ketika itu tidak bisa kita gambarkan. Sebab, sampai saat ini belum ada historiografi yang berbicara sejarah sosial masyarakat Kerajaan Banjar.

Ramainya dentuman sosial politik di era Sultan Tahmidullah ini menyisakan satu persoalan sosial keagamaan yang menarik di tengah

${ }^{3}$ Surat-Surat Perdjandjian Antara Kesultanan Bandjarmasin Dengan Pemerintahan VOC, Bataafse Republik, Inggris dan Hindia Belanda 1635 - 1860, Arsip Nasional RI., Kompartimen Perhubungan Dengan Rakyat, Jakarta, 1965, hlm 70-107 dan 123-125.

${ }^{4}$ Muhammad Idward Saleh, Bandjarmasin, hlm. 96 - 97. 
masyarakat pada bidang hukum. Perombakan lembaga hukum agama, yang sebelumnya dijalankan oleh penghulu, menjadi mabkamah syariyyah dengan pejabat utama Mufti dan Kadi. Pertanyaan yang muncul adalah apa kaitan pergolakan sosial politik tadi dengan perombakan lembaga hukum?

Kita simpan pertanyaan tadi. Kita lirik dahulu masa Sultan Adam. Pada periode ini gambaran kondisi politik Kerajaan juga tidak tercatat rinci. Ada yang mengatakan bahwa Banjar berada dalam proses degradasi akibat kerasnya permainan politik terhadap Belanda tetapi ada pula yang mengatakan bahwa Banjar mengalami masa yang damai dan tentram.

Meski berita yang sampai sangat sedikit, era Sultan Adam tidak bisa dilepaskan dari konteks sebelumnya. Ini dimulai dari periode kakeknya yang sangat terkenal kuat, Sultan Tahmidullah. Seperti dipaparkan sebelumnya, Belanda sangat dirugikan oleh politik Tahmidullah yang banyak menipu dan tidak menjalankan isi kontrak. Meski meninggalkan kekuasaan yang luas, tetapi secara politik, Kerajaan Banjar rapuh. Tak ada orang yang mampu berkuasa secara kuat karena seringnya konflik politik terjadi di Kerajaan.

Hal itu terlihat di masa Sultan Sulaiman (1801-1825), ayah Sultan Adam, pengganti Tahmidullah. Sultan Sulaiman dikenal sebagai penguasa yang sangar dan otoriter. Ia tidak akan membiarkan ada yang mengganggu kekuasaannya termasuk para bangsawan yang dikenal tergabung dalam dewan mahkota. Gerakan-gerakan penentangnya disingkirkan. ${ }^{5}$ Pada masa Sultan Sulaiman ini terjadi beberapa kontrak dengan Belanda yang mengharuskan Banjar menyerahkan sejumlah daerah kepada mereka. ${ }^{6}$ Dalam catatan arsip tersebut dapat terbaca bahwa Sultan Adam selalu dilibatkan dalam perjanjian. Ini terjadi bukan hanya di masa ayahnya berkuasa tetapi juga selama kakeknya menjadi Sultan.

Melihat gambaran di atas sekilas bisa dikatakan bahwa Kerajaan Banjar memang mengalami krisis politik. Kedudukan Sultan Adam bukanlah pada masa yang dikatakan damai tetapi upaya untuk bertahan dari kehancuran. Selama berkuasa Sultan Adam harus rela dipaksa Belanda melakukan perjanjian-perjanjian yang sekali lagi harus mengurangi wilayah kekuasaannya. Sultan Adam sadar bahwa ia tidak dapat berbuat banyak untuk mempertahankan Kerajaan Banjar meski rakyat mendukungnya. Realitas

\footnotetext{
5 Abdurrahman SH., MH., Studi Tentang Undang-Undang Sultan Adam ; Suatu Tinjauan Tentang Perkembangan Hukum dalam Masyarakat dan Kerajaan Banjar pada Pertengahan Abad Ke-19, Banjarmasin, STIHSA, 1989, hlm. 34

${ }^{6}$ Lihat Surat-Surat Perjanjian, hlm $144-153$.
} 
obyektif politik Kerajaan Banjar telah dipegang oleh Belanda. Kerajaan Banjar hanya menjadi aparatus yang menjalankan kekuasaan Belanda. Menurut Syamsiar Seman, kekuasaan Sultan pada akhirnya hanya kepada masyarakat Banjar saja.

Menurut cerita, Sultan Adam merupakan pribadi yang disenangi rakyat. Ia merupakan orang yang teguh terhadap prinsip agama dan sangat memperhatikan dengan ketenteraman dan kesejahteraan rakyatnya. Ia juga dikenal dekat dengan ulama. Ada yang memperkirakan ia pernah mendapat pelajaran dari Syekh Muhammad Arsyad al-Banjari, teman sekaligus penasehat kakeknya. Semasa berkuasa ia pun banyak mempunyai guru sekaligus penasehatnya yaitu Mufti Haji Jamaluddin, putra Syekh Muhammad Arsyad alBanjari.

Masyarakat Banjar sangat menghargai orang yang taat dalam beragama, tetapi itu ditunjukkan lewat pandangan formal. Artinya rukun Islam yang lima, terutama sholat yang menjadii aktifitasnya sehari-hari, disamping dekat dengan ulama meskipun yang bersangkutan memiliki catatan politik yang tidak baik. Misalnya saja, kebijakan Sultan Adam menaikan pajak dua kali lipat dari masa ayahnya berkuasa. ${ }^{7}$ Tidak terekam apakah ada protes dari masyarakat terhadap kenaikan pajak ini. Penulis juga tidak mengetahui secara pasti apakah hal itu karena faktor personalitas Sultan Adam atau ada faktor-faktor lain. Sebab tidak ada catatan yang menceritakannya.

\section{Pembentukan Lembaga Hukum}

Sebelumnya, kita menyinggung sedikit perjalanan hukum pada dua periode penguasa ini yang ditandai dengan dibentuknya lembaga hukum atau lembaga peradilan yang didasarkan pada syari'at Islam. Lembaga ini dikenal dengan sebutan mabkamah syariyyah. Pejabat yang duduk di lembaga ini berada satu tingkat di bawah mangkubumi yang dalam struktur pemerintahan Kerajaan Banjar berada di bawah Sultan. ${ }^{8}$ Dengan demikian, lembaga hukum ini menjadi salah satu lembaga tertinggi Kerajaan. Ada satu pertanyaan, siapa yang memprakarsai mabkamah syar'iyyah ini? Ada yang mengatakan pembentukan

\footnotetext{
${ }^{7}$ Abdurrahman SH., MH., Studi Tentang Undang-Undang Sultan Adam ; Suatu Tinjauan Tentang Perkembangan Hukum dalam Masyarakat dan Kerajaan Banjar pada Pertengahan Abad Ke-19, hlm. 39

${ }^{8}$ Ada kemungkinan bahwa jabatan Mufti ini sejajar dengan Mangkubumi. Sebab, ulama juga berperan sebagai penasehat Sultan.
} 
tersebut adalah prakarsa Sultan Tahmidullah. Ada pula yang mengatakan ini adalah prakarsa Syekh Muhammad Arsyad al-Banjari.

Persoalan hukum Islam pada dasarnya adalah persoalan yang digeluti ulama. Sedangkan Sultan sebagai penguasa lebih disibukan dengan pergolakan politik dan ekonomii Kerajaan. Apalagi Kerajaan Banjar sebenarnya telah memiliki lembaga hukum yang mengurusi persoalan keagamaan dengan adanya jabatan pengbulu, khatib dan khalifah. Jadi, ada kemungkinan bahwa Sultan tidak sampai begitu jauh memikirkan perombakan lembaga hukum ini. Yang paling mungkin untuk memikirkan perombakan ini adalah ulama yang dalam konteks ini diwakili oleh Syekh Muhammad Arsyad al-Banjari beserta murid-muridnya. Ini didukung dengan aktifitas Syekh Muhammad Arsyad al-Banjari yang bergerak dalam berbagai persoalan hukum Islam, di samping pendidikan.

Secara tersirat, sejarah mengungkapkan bahwa masyarakat sepertinya belum begitu mengerti dengan tindakan-tindakan yang berdasarkan aturan Islam. Karya-karya hukum Islam Syekh Muhammad Arsyad al-Banjari banyak berbicara tentang hal-hal keseharian seperti haid, faraid, nikah dan ibadah lainnya. Kehadiran karya-karya tersebut secara tidak langsung menjelaskan konteks keadaan masyarakat yang tidak banyak mengerti tentang hukum Islam. Selanjutnya, ada kemungkinan bahwa Syekh Muhammad Arsyad al-Banjari ingin agar hukum Islam bisa diterapkan oleh segenap masyarakat.

Untuk itu Syekh Muhammad Arsyad al-Banjari mengajukan proposal kepada Sultan Tahmidullah untuk membentuk lembaga hukum yang berkaitan dengan persoalan-persoalan tadi. Bagi Syekh Muhammad Arsyad al-Banjari ini bukan hal yang sulit. Sebab, Syekh Muhammad Arsyad al-Banjari adalah bagian dari Kerajaan dan mempunyai wibawa yang sangat tinggi. Sultan sangat menghargai usaha ini. Untuk itu Sultan menyerahkan wewenang sepenuhnya kepada Syekh Muhammad Arsyad al-Banjari.

Tidak ada berita yang memberikan napak tilas proses terbentuknya mabkamah syar'iyyah ini bahkan tidak ada catatan tertulis kapan resminya lembaga ini dibentuk. Menurut Abdurrahman SH.,MH., pembentukan ini diperkirakan terjadi sekitar tahun 1790-1795 setelah Syekh Muhammad Arsyad al-Banjari merampungkan kitab sabilal muhtadin. Mabkamah syariyyah memiliki dua jabatan tinggi dalam struktur Kerajaan Banjar, yaitu Mufti dan Kadi.

${ }^{9}$ Di dalam pemerintahan Islam di Turki dan Mesir abad ke-10 H lembaga hukum yang dipegang oleh qadhi dinamakan pengadilan syar't, sedangkan lembaga hukum yang dijalankan sendiri oleh penguasa dinamakan dengan pengadilan 'urf. Terkadang, kedua lembaga hukum ini bertentangan dan biasanya pengadilan 'urf yang lebih berkuasa, sehingga ia bisa mengalahkan 
Sebagai pejabat tertinggi, Mufti berfungsi sebagai hakim tertinggi, penasehat keagamaan dan pengawas pengadilan Kerajaan Banjar secara keseluruhan. ${ }^{10}$ Sedangkan Kadi berfungsi sebagai pelaksana hukum yang mengatur jalannya mahkamah syar'iyyah. ${ }^{11}$

Lalu, siapakah Mufti dan Kadi pertama? Sekilas kita mengira Syekh Muhammad Arsyad lah yang menjadi Mufti. Tidak ada satu pun catatan yang menyebutkan bahwa Syekh Muhammad Arsyad al-Banjari yang memegang jabatan itu. Menurut Syekh Abdurahman Shiddiq, Mufti pertama adalah Muhammad As'ad, cucu Syekh Muhammad Arsyad al-Banjari dari putrinya Syarifah. Sedangkan yang menjabat sebagai Kadi adalah Abu Su'ud, anak Syekh Muhammad Arsyad al-Banjari. ${ }^{12}$ Untuk selanjutnya, para pemegang dua jabatan ini adalah para ulama keturunan Syekh Muhammad Arsyad al-Banjari. ${ }^{13}$ Adapaun Syekh Muhammad Arsyad al-Banjari, menurut beberapa penuturan tetap berkonsentrasi pada pengembangan pendidikan Islam di Dalam Pagar.

Kalau dua jabatan ini berada dalam struktur Kerajaan Banjar, maka masyarakat di luar struktur tersebut pada setiap wilayah juga memiliki pejabatpejabat kegamaan yang diawasi langsung oleh mabkamah syar'iyyah. Pada tingkat lalawangan ada penghulu yang berwenang sebagai hakim dan mengawasi pejabat-pejabat agama di wilayahnya. Penghulu dibantu oleh khalifah yang mewakilinya jika berhalangan. Pada tingkat yang lebih rendah (seperti kelurahan) jabatannya dinamakan khalifah juga. Tugasnya kemungkinan sama dengan penghulu kecuali khalifah tidak punya wewenang untuk mengadili jika tidak ada pelimpahan wewenang dari penghulu. Di tingkat yang lebih rendah lagi, yaitu di kampung ada wakil penghulu. Kewenangan khususnya adalah

hukum di pengadilan syar'i meskipun bertentangan dengan syara'. Lihat Reuben Levy, Susunan Masyarakat Islam, alih bahasa A. Lujito, jilid II, YOI, 1989, hlm. 127-138.

10 Peran pejabat hukum agama di lingkungan Kerajaan Banjar agak berbeda dengan Kesultanan Palembang. Pejabat hukumnya disebut Pangeran Penghulu Nata Agama. Ia menjalankan tiga bidang utama yaitu ibadah, kekeluargaan dan kemasyarakatan. Lihat Husni Rahim, Sistem Otoritas dan Administrasi Islam ; Studi Tentang Pejabat Agama Mas Kesultanan dan Kolonial di Palembang, Jakarta, LOGOS, 1998. hlm. 106-113.

11 Abdurrahman SH., MH., Syekh Mubammad Arsyad Al-Banjari, Konseptor dan Pendiri Kerapatan Kadi di Kalimantan Selatan, Banjarmasin Post Bagian I, 30 Juni 1989.

12 Abu Daudi, Maulana Syekh Mubammad Arsyad Al-Banjari, Martapura, Madrasah Sullamul Ulum, 1996, hlm. 58.

${ }^{13}$ Menurut laporan Abu Daudi di dalam bukunya, di antara keturunan Syekh Arsyad ada delapan orang Mufti, sembilan orang Kadi dan dua orang Khalifah. 
sebagai pegawai administrasi berkenaan dengan perkawinan dan perceraian warga kampung bersangkutan. ${ }^{14}$

Dalam perjalanannya kemudian, lembaga hukum ini terus dirapikan dengan prosedur hukum yang tertata dengan baik. Ini bisa kita lihat di masa Sultan Adam. Ada satu prestasi brilian berkaitan dengan perkembangan Islam secara umum dan hukum Islam secara khusus. Sultan Adam mengeluarkan aturan hukum bagi masyarakat yang dinamai dengan Undang-Undang Sultan Adam (UUSA). Undang-undang ini disandarkan kepada nama Sultan Adam sebab ia yang menandatanganinya sebagaimana termaktub dalam pembukaan UUSA "aku Sultan Adam memboeat oendang-oendang pada sekalian rakjatku..."." Sampai sekarang prestasi ini merupakan monumen sejarah yang paling mengemuka sepanjang kekuasaan Sultan Adam dan masih memerlukan banyak kajian untuk membongkar keberadaan historisnya.

Hingga kini belum ditemukan naskah asli dari UUSA sehingga kita tidak tahu secara pasti bagaimana bentuknya, bahasa serta bentuk tulisannya. UUSA yang bisa diketahui sekarang merupakan penemuan dari pejabat Belanda yang pernah berkuasa di Banjarmasin. ${ }^{16}$

Adapun materi-materi yang termuat dalam UUSA terdiri dari persoalan agama dan peribadatan (pasal 1,2 dan 20), tata pemerintahan (pasal 3, 21 dan 31), perkawinan (pasal 4,5,6,18,25 dan 30), hukum acara/peradilan (pasal $7,8,9,10,11,12,13,14,15,19$ ) hukum tanah (pasal 17,23,26,27,28 dan 29) dan peraturan peralihan (pasal 16)

Persoalan pertama yang kita jawab adalah kapan UUSA diberlakukan? Hampir semua pengamat sejarah Banjar mengatakan bahwa UUSA mulai berlaku pada tangal 15 Muharram $1251 \mathrm{H}$ bertepatan dengan tahun 1835 Masehi. Artinya, UUSA keluar (diperkirakan) setelah 10 tahun Sultan Adam

14 Alfani Daud, Islam dan Masyarakat Banjar; Deskripsi dan Analisa Kebudayaan Banjar, Jakarta, RajaGrafindo Persada, 1997, hlm. 56

15 Undang-Undang Sultan Adam ini diambil dari Adatrecht Bundels, Bezorgd Door De Commissie Voor Het Adatrecht En Vitgegeven Door Het Koninklijk Instituut Voor De Taal-, Land En Volkenkunde Van Nederlandsch-Indie, Volume XIII, Borneo's-Gravenhage, Martinus Nijhoff, 1917, hlm 343 - 354

16 Eisenberger menyebutkan bahwa ia mendapati sebuah naskah tulisan tangan di Martapura namun sesudah itu naskah tersebut tidak pernah lagi diketahui. Publikasi pertama naskah UUSA dilakukan oleh A.M. Joekes di dalam majalah Indische Gids pada tahun 1891. Naskah ini kemudian ditulis kembali oleh komisi hukum adat Belanda dan diterbitkan dalam Adatrecht Bundels volume XII tahun 1917. Selain naskah Martapura, Eisenberger juga mengungkapkan adanya naskah yang agak berbeda dari sebelumnya dan disebut dengan naskah Amuntai. Namun, naskah Martapura lebih banyak diketahui orang daripada naskah Amuntai. 
berkuasa. Dasar dari waktu pemberlakuan ini adalah pembukaan UUSA itu sendiri yang berbunyi " pada hoedzrat 1251 pada hari kamis yang kalima belas hari boelan almoeharram djam poekoel sambilan..."

Persoalan kedua adalah apa tujuan pembentukan UUSA ini. Para ahli hukum adat mengatakan bahwa hal ini wajar dilakukan oleh para Raja sebagai penguasa. Tujuan dari pembentukan ini tersurat dalam naskah tersebut " akoe Soeltan Adam membuat oendang-oendang pada sekalian ra'jatkoe soepaja djadi sempoerna agama rajjatkoe dan atikat mereka itoe dan soepaja djangan djadi banjak djadi-djadi perbantahan mereka itoe dan soepaja djadi kemoedaban segala hakim-bakim manghoekoemkan mereka itoe akoe barap harap djoea bahwa djadi baik sekalian hal mereka itoe dengan sebab oendang-oendangkoe ini..."

Dari bunyi pembukaan tersebut setidaknya ada tiga hal yang menjadi pertimbangan mengapa UUSA ini dikeluarkan. Pertama, untuk menyempurnakan agama dan kepercayaan rakyat Banjar. Kedua, untuk mencegah konflik di masyarakat. Ketiga, untuk menjadi pegangan para hakim dalam menangani suatu perkara.

Selain persoalan-persoalan yang telah dibicarakan di atas satu hal lagi yang menjadi tanda tanya yaitu mengapa Undang-undang ini dikeluarkan setelah sepuluh tahun Sultan Adam berkuasa. Tidak ada informasi yang menjelaskan ini. Menurut Abdurrahman SH., MH., ini hanya soal teknis saja. Tetapi ada kemungkinan lain yang bisa kita tarik secara logis. Seorang penguasa, terlebih seperti Sultan Adam yang dikenal berpendidikan dan mendapatkan pengalaman politik bersama para penguasa sebelumnya, akan menjalankan kebijakannya sejak awal ia menduduki tahta termasuk persoalan hukum, pendek kata, ia tidak memerlukan waktu lama untuk memformulasi perangkat hukum Kerajaan, apalagi hukum tersebut berdasarkan hukum Islam. Ia bisa menyerahkan kepada sebuah tim (yang beranggotakan ulama) yang bekerja menggodok peraturan-peraturan tersebut. Sepuluh tahun bukanlah waktu yang pendek untuk kita katakan sebagai kendala teknis saja. Kalau menilik kepada perjalanan penguasa Kerajaan Banjar sebelumnya, tidak pernah

17 Pendapat berbeda pernah dilontarkan Artum Artha. Menurutnya, UU tersebut berlaku pada tahun 1825, bukan 1935 sebagaimana disepakati banyak orang. Lebih jauh, ia menceritakan bahwa semasa Sultan Sulaiman berkuasa, Sultan Adam menjabat sebagai Menteri Urusan Agama. Kala itu ia diperintah untuk membuat UU kerajaan. Sultan Adam bekerjasama dengan ulama. Setelah ayahnya meninggal pada 1825, Sultan Adam naik tahta dan selanjutnya ia memberlakukan rancangan UU yang telah disusun sebelumnya sebagai UU kerajaan. Lihat Abdurrahman SH., MH., Studi tentang, hlm. 51 -52. 
ada Sultan yang mengeluarkan undang-undang selain Kutara Arya Trenggana yang diberlakukan pada masa Sultan Suriansyah.

Persoalan ini mungkin bisa dijawab secara tersirat oleh pembukaan UUSA yang bertitik tumpu pada ranah filosofis, sosiologis dan yuridis. Kesulitan kita adalah tidak adanya informasi yang melukiskan realitas masyarakat waktu itu yang katanya agama dan kepercayaan mereka belum sempurna, perselisihan di masyarakat yang sering terjadi serta lembaga peradilan yang belum rapi. Selain itu, kita juga tidak mendapatkan apakah ada hubungan antara realitas politik dengan pemberlakuan UUSA.

Ada satu informasi yang mengatakan bahwa pada masa Sultan Adam pajak dinaikan dua kali lipat dari sebelumnya. Kebijakan ini diambil karena kekuasaan Sultan yang semakin menyempit yang berimbas pada berkurangnya pendapatan Kerajaan. Hal ini tentunya sangat berpengaruh terhadap masyarakat. Menurut cerita, kenaikan ini memberatkan masyarakat sehingga pada tahun 1854 masyarakat Batang Balangan mengadu kepada residen Belanda untuk pindah berada di bawah kekuasaan mereka dari pada berada di bawah Kerajaan Banjar. ${ }^{18}$ Namun demikian, tidak didapat informasi kapan kenaikan pajak itu dilaksanakan, apakah sebelum UUSA atau sesudahnya. ${ }^{19}$

Selain dibentuknya UUSA, periode Sultan Adam juga ditandai dengan perubahan struktur jabatan di lembaga hukum. Sebelumnya kita mengenal Kadi. Di masa Sultan Adam berubah nama menjadi hakim.

Tidak ada catatan pasti yang menginformasikan perubahan jabatan ini. Amir Hasan Kiai Bondan tidak menulis adanya Kadi dalam susunan

18 Yustan Azidin dkk, Sejarah Perlawanan Terbadap Kolonialisme dan Imperialisme di Kalimantan Selatan, Banjarmasin, Depdikbud, 1982, hlm. 30.

${ }_{19}$ Kenaikan pajak dua kali lipat merupakan beban tersendiri bagi rakyat banyak (jaba). Di sini secara tidak langsung mengindikasikan rakyat harus lebih keras bekerja untuk memenuhi kewajiban tersebut. Sedangkan elit kerajaan hanyalah agen daerah dari kekuasaan Belanda yang berpusat di Batavia. Menurut salah satu catatan, mereka juga digaji Belanda. Kata "pemerasan" atau "penindasan" akhirnya terjadi jika keadaan sejarahnya demikian. Keadaan seperti ini tidak menutup kemungkinan meimbulkan reaksi dari rakyat sendiri. Sayang! Tak ada satu pun cerita atau catatan tentang sikap rakyat tadi. Jika kenaikan pajak ini beriringan dengan dengan pemberlakuan UUSA, kita akan dapat menangkap gerak sejarah yang terjadi kala itu. Hukum secara sosiologis adalah menjaga berbagai anomali sosial yang terjadi termasuk di antaranya menjaga interkasi antar kelompok di masyarakat tertata baik. Dari sudut politik, hukum menjadi alat untuk mengendalikan kekuasaan terhadap gerak yang bisa membahayakannya. Jika kenyataan dari kenaikan pajak dan UUSA seperti ini maka keberadaan UUSA mempunyai dimensi politik yang sangat kental. 
pemerintahan Sultan Adam. ${ }^{20}$ Ia justru menulis jabatan penghulu yang berfungsi sebagai hakim. Untuk mengetahui apakah berita ini valid atau tidak, bisa kita lihat lewat UUSA. Dalam pasal-pasal yang termaktub tidak disebutkan jabatan Kadi yang berwenang menjadi pelaksana hukum tetapi hakim. Apakah ini berarti Kadi sudah ditiadakan?

Abdurrahman SH., MH., memberika hipotesa bahwa jabatan Kadi pada masa Sultan Adam kemungkinan besar tidak dihapuskan tetapi tidak difungsikan. Lebih jauh lagi, ia mengatakan jabatan Kadi langsung diambil alih oleh Sultan Adam. Hal ini didasarkan pada fungsi Sultan selaku penguasa politik dan agama. Kendati demikian, tidak dijelaskan mengapa Sultan Adam mengambil alih fungsi Kadi itu. Apakah karena ia seorang yang mengerti banyak persoalan agama? Atau ada maksud lain dari pengambil alihan ini?

Pendapat di atas mungkin ada benarnya. Sebab, di dalam UUSA disebutkan bahwa jika hakim tidak bisa mengambil keputusan maka urusannya (perkara) harus diserahkan kepada Sultan (dalam UUSA tertulis "bapadah kajah diakoe"). Tetapi, bagaimana sebenarnya gambaran kerja Kadi? Kalau Kadi masuk dalam jabatan keagamaan tertinggi dan kemudian diambil alih oleh Sultan Adam bagaimana menjawab persoalan ada beberapa gelar Kadi pada keturunan Syekh Muhammad Arsyad al-Banjari yang tidak lain adalah para individu yang menguasai persoalan agama? bagaimana gambaran posisi mereka? Apakah gelar itu sebatas gelar kehormatan atau memang fungsional?

\section{Arah Sejarah dan Realitas Hukum Di Kerajaan Banjar}

Secara umum, abad ke-18 di Nusantara adalah masa dimana kolonialisme Belanda mulai meradang. Gejolak politik kolonialisme sangat besar pengaruhnya meskipun pada awalnya hanya untuk urusan ekonomi saja. Seluruh Kerajaan di Nusantara pada waktu itu sama-sama mempunyai satu lawan ekonomi sekaligus lawan politik yang pada akhirnya wilayah-wilayah itu jatuh dalam cengkeraman penjajah Barat. ${ }^{21}$

Begitu pula yang terjadi di Kerajaan Banjar. Dua periode kekuasaan yang kita bicarakan ini berada dalam ruang yang penuh dengan upaya mempertahankan eksistensinya. Sultan Tahmidullah dikenal tangguh dan licin dalam menjalankan politiknya sehingga pernah membuat Belanda berpikir

\footnotetext{
${ }^{20}$ Amir Hasan Kia Bondan, Sulub Sejarah Kalimantan, Banjarmasin, Fajar, hlm. 150

21 W. F. Wertheim, Masyarakat Indonesia dalam Transisi, alih bahasa Zulfa Elizabet, Yogyakarta, Tiara Wacana, 1999, hlm 42 - 48.
} 
panjang untuk berhubungan dengan Banjar. Begitu pula cucunya, Sultan Adam. Ia dikenal sebagai penguasa yang bekerja keras mempertahankan keutuhan Kerajaan. Yang menarik dari masa Sultan Adam adalah survivalitas yang tidak berbasis secara politik tetapi melalui hukum.

Periode Tahmidullah ditandai dengan perebutan kembali wilayah kekuasaan yang hilang. Ia bekerja sama dengan Belanda dan memberikan konsesi monopoli perdagangan serta wilayah yang luas meskipun kemudian diingkarinya. Tetapi, kemenangan sementara Belanda ini berakibat pada rapuhnya Banjar pada perjalanan selanjutnya. ${ }^{22}$ Sultan Tahmidullah memang didukung elit Kerajaan (sebagian besar anggota dewan mahkota). Namun, di lain pihak, masyarakat tidak terlalu bersimpati. Menurut cerita, masyarakat lebih mendukung Pangeran Amir yang dianggap lebih berhak atas tahta sepeninggalan Sultan Aliuddin Aminullah.

Hingga kini, tidak didapat keterangan pasti apakah Tahmidullah didukung rakyat atau tidak? Masyarakat kemungkinan besar mengetahui keadaan waktu itu tetapi tidak mempunyai kekuatan melakukan perimbangan politik. ${ }^{23}$ Jika ini benar, maka sedikit banyak sikap benci serta antipati berlangsung di masyarakat terhadap elit penguasa. Tetapi masyarakat tidak bersuara dan seolah dimaafkan saja sebagai imbas dari ketidakmampuan politik tadi. Kalau kemungkinannya seperti ini maka sikap dingin masyarakat terhdap Sultan Tahmidullah bukan hanya pada persoalan normatif saja (memberi maaf) tetapi juga ada kemungkinan lain yang dicoba untuk kita lihat, yaitu pengaruh hubungan ulama dengan penguasa.

Ulama adalah kelompok sosial yang sangat dihormati. Masyarakat memandang sosok mereka sebagai tumpuan sekaligus panutan sehingga orang manapun yang dekat dengan ulama dianggap orang baik, kendati orang tersebut memiliki catatan (politik, ekonomi) yang buruk. Disini Sultan Tahmidullah

22 Menurut Wertheim kerajaan-kerajaan maritim Indonesia tidak mampu berhadapan dengan kekuatan ekspansi Barat. Struktur internal pemerintahan mereka tidak memenuhi syarat untuk memiliki sebuah kekuasan wilayah (negara) yang kuat. Ini terbukti dengan sulitnya mereka bekerjasama dengan masyarakat yang hanya menganggap mereka sebagai obyek eksploitasi.

23 Sama seperti bentuk pemerintahan otokrasi tradisional yang lain, masyarakat di Kerajaan Banjar yang terstrata dalam kelas jaba tidak mempunyai klik politik. Mereka cenderung pasif dan apatis dengan lingkungan sosial politiknya, disengaja atau tidak. Nalar mereka diambil alih penguasa sebagai orang yang diurusi bukan mengurusi. Gambaran otokrasi tradisonal bisa dilihat dalam Charles F. Andrain, Kebidupan Politik dan Perubaban Sosial, alih bahasa Luqman Hakim, Yogyakarta, Tiara Wacana, 1992, hlm. 342. 
diuntungkan. Di masa kekuasaannya hidup satu sosok ulama yang sangat disegani di Banjar dan Nusantara, yaitu Syekh Muhammad Arsyad Al-Banjari. Syekh ini dikenal dekat dengan Kerajaan sebab sejak kecil ia sudah diasuh oleh Sultan. Bahkan, studinya pun disponsori oleh Kerajaan. Sepulangnya dari Mekkah ia lebih dahulu mampir di Kerajaan sampai kemudian berdiam di luar memfokuskan diri pada pengembangan Islam. ${ }^{24}$

Pertemanan yang dibina Sultan Tahmdullah dengan Syekh Muhammad Arsyad al-Banjari tidak bermula ketika ia menjadi Sultan. Tetapi sudah sejak kecil. Jadi, bisa dipastikan Syekh Muhammad Arsyad al-Banjari mengetahui apa yang berlaku kala itu. Lantas bagaimana sikap Syekh Muhammad Arsyad alBanjari ? Tidak ada data yang menjelaskan ini. Bisa jadi, Syekh Muhammad Arsyad al-Banjari tidak berkepentingan dengan itu semua. Mungkin, kepentingan yang dibawanya adalah mengembangkan kehidupan Islam di masyarakat Banjar.

Hubungan antara Sultan Tahmidullah sebagai elit penguasa dengan Syekh Muhammad Arsyad al-Banjari sebagai elit masyarakat sepertinya berjalan mulus. Sebab, selaku penguasa ia mempunyai kepentingan politik yaitu dukungan dari elit baik berupa dukungan politik (bangsawan dan keluarga Kerajaan) ataupun dukungan moral (ulama). Ini sangat diperlukan untuk mengatasi sikap tak bersahabat masyarakat. Apalagi masyarakat lebih memilih ketaatan terhadap ulama dibanding dengan penguasa. Karena itu, kehadiran Syekh Muhammad Arsyad al-Banjari yang sangat kharismatik menjadi point tersendiri bagi Sultan Tahmidullah. ${ }^{25}$

Di samping kepentingan yang dibawa oleh Sultan, ada pula kepentingan yang dibawa oleh Syekh Muhammad Arsyad al-Banjari, yaitu pengembangan

${ }^{24}$ Pada abad ke 18, generasi ulama jaringan Timur Tengah berasal dari Palembang (Syekh Abdussamad Al-Palimbani), Kalimantan Selatan (Syekh Muhammad Arsyad al-Banjari dan Syekh Muhammad Nafis al-Banjari), Sulawesi (Syekh Abdul Wahab Bugis, Batavia (Syekh Abdurrahman Al-Mashri Al-Batawi) dan dari Fatani, Thailand Selatan (Syekh Dawud bin Abdullah). Lihat ulasan Azyumardi Azra, Jaringan Ulama Timur Tengah dan Nusantara Abad XVII dan XVIII, Bandung, Mizan, 1999, hlm. 106-239.

25 Ada beberapa cara bagi penguasa mendapatkan legitimasi dari masyarakat. Cara-cara tersebut dikelompokan menjadi simbolis, prosedural dan materiil. Dalam pemerintahan tradisional, upaya mendapatkan legitimasi cenderung dengan cara simbolis. Contohnya, kepercayaan terhadap orang berdarah biru sebagai pemimpin dan kedekatan dengan orang yang berpengaruh di masyarakat. Lihat Ramlan Surbakti, Memahami Ilmu Politik, Jakarta, Grasindo, 1992, hlm. $96-97$. 
syiar Islam. ${ }^{26}$ Upaya ini dijalankan Syekh Muhammad Arsyad al-Banjari melalui jalur pendidikan (Madrasah Dalam Pagar) dan hukum (pembentukan lembaga hukum Islam). Dengan kata lain, Islam secara kultural digerakan melalui pendidikan dan secara sturktural melalui lembaga hukum. Rencana pembentukan lembaga hukum ini disetujui oleh Sultan dan diserahkan kepada Syekh Muhammad Arsyad al-Banjari untuk pengelolaannya. Pembentukan lembaga ini jelas tidak memberi pengaruh negatif terhadap kekuasaan, tapi justru menjadi kekuatan politik bagi penguasa.

Dari sini, terdapat kemungkinan bahwa keberadaan lembaga hukum merupakan manifestasi dari tawar-menawar kepentingan antara elit penguasa dengan elit masyarakat. Artinya, lembaga hukum tidak secara murni berada dalam ruang normatif tetapi juga sub stratum sosial. ${ }^{27}$

Kemungkinan realitas seperti ini juga nampak pada periode Sultan Adam. Namun, perkembangan politik yang berlangsung agak berbeda dari Sultan Tahmidullah. Banjar di masa Sultan Adam sudah berada di bawah kekuasaan Belanda dan hanya berstatus sebagai negara vasal kendati masih diakui sebagai sebuah Kerajaan. Kebijakan-kebijakan Belanda sulit diindahkan oleh Sultan Adam. Sebab, kekuatan politiknya sangat lemah. Walaupun demikian, Belanda tetap memberi ruang Sultan Adam untuk memimpin masyarakat.

Jika kenyataannya demikian, bagaimana membuat benang logis dengan keluarnya UUSA 1835 serta pergeseran posisi Kadi? Sekilas sepertinya tidak terjadi apa-apa, namun jika melihat kepada upaya menjaga atau menunjukan eksistensi Kerajaan, nampak sedikit jejak yang masuk akal. Satu sisi, kekuatan politik sudah tidak berada di tangan Sultan lagi. Di sisi lain, Banjar masih diakui sebagai Kerajaan. Untuk itu, Sultan dituntut mampu menterjemahkan pengakuan ini menjadi "seperti" kekuasaan politik. Strateginya adalah melalui pemberlakuan hukum. Sebab, secara teoretis, hukum merupakan upaya menjaga, menata sekaligus mengontrol jalannya kehidupan sosial. Peluang

${ }^{26}$ Apa yang dilakukan oleh Syekh Arsyad merupakan idealisme yang dibawa para ulama Nusantara secara umum. Menurut Azra, gagasan-gagasan pembaharuan yang dilakukan tidak berorientasi politik tetapi bersifat religius. Tema pokoknya adalah kembali pada ortodoksi Sunni dengan ciri utamanya adalah keselarasan antara syari'at dan tasawwuf. Azyumardi Azra, Jaringan Ulama, hlm. 240-241.

${ }^{27}$ David Lockwood mengkritik Parson yang dianggap berat sebelah. Parson dituduh hanya melihat realitas sosial sebagai sesuatu yang berjalan normatif. Padahal, menurut Lockwood, ada sub stratum sosial, terutama kondisi-kondisi kepentingan yang bisa menghasilkan konflik sosial dan ketidak seimbangan yang cenderung diindahkan sebagai faktor umum yang menentukan dinamika sosial. 
untuk melakukan hal ini tersedia dan dengan berlakunya UUSA berarti kekuasaan Sultan Adam belum habis alias masih ada (exist). Selain itu, adanya pergeseran peran Kadi menjadi hakim juga menarik untuk disimak. Jika sebelumnya, di masa Sultan Tahmidullah, Kadi adalah jabatan tertinggi yang menangani persoalan-persoalan agama maka di masa Sultan Adam fungsi Kadi diambil alih langsung oleh Sultan. Untuk persoalan-persoalan agama secara umum diserahkan kepada hakim saja. Di sini kita kembali bisa melihat bahwa ketika kekuasaan politik sudah memudar penguasa bisa menggunakan sumber kekuatan yang lain untuk tetap berkuasa yaitu kekuasaan agama.

Di samping pergeseran peran di atas, Sultan Adam juga merapikan perangkat peradilan. Ada 10 pasal yang memuat peradilan dan hukum acara dan bidang ini merupakan peraturan terbanyak dalam UUSA. Hal ini memperjelas upaya menjaga eksistensi kekuasaan Banjar melalui ranah hukum. Dengan kata lain, merapikan hukum bisa berarti merapikan kekuasaan.

Sosok Sultan Adam tidak seperti pendahulunya. Ia dikenal sebagai seorang terdidik dan memiliki catatan politik yang lumayan bersih. Ia juga dikenal dekat dengan ulama. Tetapi, ada satu kebijakan yang perlu kita kaji semasa kepemimpinannya, yaitu, kenaikan pajak. Sayangnya, kita tidak mendapatkan yang pasti kapan terjadinya putusan kenaikan pajak itu.

Namun demikian, jika melihat ke dalam UUSA, akan terdapat komposisi aturan yang banyak mengatur masalah tanah. Ada 6 pasal yang mengatur masalah tanah. Isinya tampak normatif dan tidak berbenturan dengan wacana fiqh. Akan tetapi, jika kita melihatnya dari sudut pandang yang lain, bisa jadi akan menggelitik.

Dalam sebuah kekuasaan tradisional seperti Banjar, semua tanah yang yang berada di wilayah kekuasaan Banjar adalah milik Kerajaan Banjar kecuali jika ada izin penguasa untuk mengelolanya. UUSA memulai pembahasan tanah pada pasal 17. Di dalamnya dijelaskan bahwa siapa saja yang memiliki tanah yang berada dalam proses muamalat harus dicatat dalam sebuah prosedur administratif kerajaan. Padahal, di satu sisi, kita tahu bahwa pemilik tanah pada masa itu hanya elit kerajaan, bangsawan dan elit masyarakat. Lantas apa urgensitas pemberlakuan hukum ini?

Ada kemungkinan peraturan ini berkaitan dengan penguasaan tanah yang berkurang sejak kedatangan Belanda. Apanage yang selama ini ada di tangan para bangsawan kerajaan memiliki masalah dan oleh karena itu perlu diatur secara formal. Semua tanah yang tersisa dari kekuasaan Banjar memerlukan pendataan dan penghitungan kembali untuk memastikan wilayah-wilayah mana 
saja yang masih tetap di bawah kekuasaan Banjar. Memang, isi dari pasal-pasal pertanahan tidak menunjukan cacat apalagi yang bertentangan dengan maslahah, tetapi bagaimanapun juga konteks sosial politik ini sangat penting untuk membongkar pecahan-pecahan sejarah yang terlupakan, disengaja atau tidak!

Lembaga hukum merupakan alat praksis untuk menata kehidupan sosial. Namun demikian, sebagaimana diungkapkan pada bagian awal tulisan ini, agar hukum mampu berjalan di masyarakat harus ada kekuatan pemaksa yang mampu menjalankan serta mengendalikan hukum. Dalam konteks sejarah hukum yang kita bincangkan ini, lembaga hukum mendapat tempat yang sangat penting.

Lembaga hukum dibutuhkan sebab tidak selamanya penguasa bisa menangani bidang ini. Sebab, ia lebih banyak berkecimpung dengan dunia politik dan ekonomi (perdagangan). Di samping itu kebanyakan penguasa tidak begitu mengerti dengan seluk beluk persoalan hukum. Jadi, persoalan ini diserahkan kepada orang yang menekuni dan mampu menanganinya.

Masyarakat Banjar merupakan masyarakat yang dikenal kental dengan (tradisi) Islam dan ini berlanjut pada persoalan kepatuhan sosial. Masyarakat lebih patuh kepada pemuka agama ketimbang penguasa. Sehingga kekuasaan hukum yang dijalankan ulama mengandung kepatuhan secara formal sekaligus non formal.

Bisa jadi, pada arus umum, masyarakat tidak terlalu pusing dengan bentuk lembaga hukum seperti apa yang mau dikelola. Mereka lebih melihat kepada siapa yang menjalankannya. Jika ini shabih, tidak salah kiranya Alfani Daud memprediksikan bahwa kemungkinan tidak adanya lagi jabatan hukum sekuler pada paruh kedua perjalanan Kerajaan Banjar. Hal ini juga menunjukan bahwa gerak sejarah hukum yang terjadi menurut perjalanan sosial ketika itu yang lebih cenderung menggunakan aturan sosial Islam daripada aturan umum atau sekuler.

Pada arus yang lain, yakni dalam diri penguasa (Sultan), tidak menganggap suatu masalah jika aturan sosial masyarakat berdasarkan pada hukum Islam. Alasannya pertama, masyarakat pada waktu itu telah lama memeluk Islam. Kedua, faktor ulama sebagai sosok yang bisa diterima oleh semua pihak dan menjadi perekat sosial. ${ }^{28}$

Coba kita lihat sekali lagi! Di masa Sultan Tahmidullah, peran lembaga hukum mengalami eskalasi. Jika sebelumnya, lembaga hukum Islam hanya menjadi "suplemen" kerajaan, setelah itu justru makin prestisius. Lembaga

${ }^{28}$ Alfani Daud, Islam dan Masyarakat Banjar, hlm. 57 
hukum ini memiliki kekuatan yang tidak dimiliki lembaga politik Kerajaan Banjar, yaitu kekuatan kultural. Kekuatan yang dimaksud adalah sumber daya potensial untuk menjadi pemersatu yang mampu mengintegrasikan masyarakat. Meskipun di satu pihak, Sultan mungkin mampu mengintegrasikan Banjar secara politik.

Di sini Kerajaan Banjar hanya memiliki dua kekuatan yang tersisa untuk tetap bertahan. Pertama, kekuatan politik yang ada pada lembaga pemerintahan. Kedua, kekuatan Islam yang melekat pada lembaga hukum. Namun, dua kekuatan ini hanya mampu bertahan hingga krisis politik di masa Sultan Adam. Sebab, di penghujung kekuasaan Kerajaan Banjar, Sultan tidak memiliki kekuatan politik lagi. Hanya tinggal kekuatan kultural lah yang tetap berjalan dan dibungkus seolah-olah masih menyimpan kekuatan struktural.

\section{Penutup}

Begitulah perjalanan hukum di tengah masyarakat dan Kerajaan Banjar. Ia bisa berbelok ke mana saja bahkan lurus sekalipun. Ini semua kembali pada ke mana arah sejarah itu berjalan dan bertelikung! Kenyataan yang harus kita pelajari saat ini adalah hukum tidak berada pada satu susunan harapan yang tanpa kaki dalam lintasan sejarah. Hukum justru sangat kental dengan perbenturan tanpa henti dengan kehendak-kehendak zaman di mana hukum tersebut ada [] 


\section{DAFTAR PUSTAKA}

Abdurrahman, Studi Tentang Undang-Undang Sultan Adam ; Suatu Tinjauan Tentang Perkembangan Hukum dalam Masyarakat dan Kerajaan Banjar pada Pertengahan Abad Ke-19, Banjarmasin, STIHSA, 1989.

Abdurrahman, Syekh Mubammad Arsyad Al-Banjari, Konseptor dan Pendiri Kerapatan Kadi di Kalimantan Selatan, Banjarmasin Post Bagian I, 30 Juni 1989.

Abu Daudi, Maulana Syekh Muhammad Arsyad Al-Banjari, Martapura, Madrasah Sullamul Ulum, 1996.

Alfani Daud, Islam dan Masyarakat Banjar ; Deskripsi dan Analisa Kebudayaan Banjar, Jakarta, RajaGrafindo Persada, 1997.

Amir Hasan Kia Bondan, Sulub Sejarah Kalimantan, Banjarmasin, Fajar.

Andrain, Charles F., Kehidupan Politik dan Perubahan Sosial, alih bahasa Luqman Hakim, Yogyakarta, Tiara Wacana, 1992.

Azidin, Yustan, dkk, Sejarah Perlawanan Terbadap Kolonialisme dan Imperialisme di Kalimantan Selatan, Banjarmasin, Depdikbud, 1982.

Azra, Azyumardi, Jaringan Ulama Timur Tengah dan Nusantara Abad XVII dan XVIII, Bandung, Mizan, 1999.

Levy, Reuben, Susunan Masyarakat Islam, alih bahasa A. Lujito, jilid II, YOI, 1989.

Rahim, Husni, Sistem Otoritas dan Administrasi Islam ; Studi Tentang Pejabat Agama Mas Kesultanan dan Kolonial di Palembang, Jakarta, LOGOS, 1998.

Saleh, Muhammad Idward, Bandjarmasin, Bandung, Balai Pendidikan Guru, 1958. 
Surat-Surat Perdjandjian Antara Kesultanan Bandjarmasin Dengan Pemerintahan VOC, Bataafse Republik, Inggris dan Hindia Belanda 1635 - 1860, Arsip Nasional RI., Kompartimen Perhubungan Dengan Rakyat, Jakarta, 1965.

Surbakti, Ramlan, Memahami Ilmu Politik, Jakarta, Grasindo, 1992.

Undang-Undang Sultan Adam ini diambil dari Adatrecht Bundels, Bezorgd Door De Commissie Voor Het Adatrecht En Vitgegeven Door Het Koninklijk Instituut Voor De Taal-, Land En Volkenkunde V an Nederlandsch-Indie, Volume XIII, Borneo's-Gravenhage, Martinus Nijhoff, 1917.

Wertheim, W. F., Masyarakat Indonesia dalam Transisi, alih bahasa Zulfa Elizabet, Yogyakarta, Tiara Wacana, 1999. 